\title{
Bread Wheat (Triticum aestivum) Responses to Arbuscular Mycorrhizae Inoculation under Drought Stress Conditions
}

\author{
Neila Abdi, Angeline van Biljon (D, Chrisna Steyn and Maryke Tine Labuschagne *(D) \\ Department of Plant Sciences, University of the Free State, Bloemfontein 9300, South Africa; \\ neilaabdi@gmail.com (N.A.); avbiljon@ufs.ac.za (A.v.B.); bothac@ufs.ac.za (C.S.) \\ * Correspondence: labuscM@ufs.ac.za
}

check for updates

Citation: Abdi, N.; van Biljon, A.; Steyn, C.; Labuschagne, M.T. Bread Wheat (Triticum aestivum) Responses to Arbuscular Mycorrhizae Inoculation under Drought Stress Conditions. Plants 2021, 10, 1756. https://doi.org/10.3390/ plants10091756

Academic Editor:

Aleksandra Orzechowska

Received: 19 July 2021

Accepted: 16 August 2021

Published: 24 August 2021

Publisher's Note: MDPI stays neutral with regard to jurisdictional claims in published maps and institutional affiliations.

Copyright: (c) 2021 by the authors. Licensee MDPI, Basel, Switzerland. This article is an open access article distributed under the terms and conditions of the Creative Commons Attribution (CC BY) license (https:// creativecommons.org/licenses/by/ $4.0 /)$.

\begin{abstract}
Abiotic constraints such as water deficit reduce cereal production. Plants have different strategies against these stresses to improve plant growth, physiological metabolism and crop production. For example, arbuscular mycorrhiza (AM) — bread wheat association has been shown to improve tolerance to drought stress conditions. The objective of this study was to determine the effect of AM inoculation on plant characteristics, lipid peroxidation, solute accumulation, water deficit saturation, photosynthetic activity, total phenol secretion and enzymatic activities including peroxidise (PO) and polyphenol oxidase (PPO) in two bread wheat cultivars (PAN3497 and SST806) under well-watered and drought-stressed conditions in plants grown under greenhouse conditions, to determine whether AM can enhance drought tolerance in wheat. AM inoculation improved morphological and physiological parameters in plants under stress. The leaf number increased by $35 \%$ and $5 \%$, tiller number by $25 \%$ and $23 \%$, chlorophyll content by $7 \%$ and $10 \%$, accumulation of soluble sugars by $33 \%$ and $14 \%$, electrolyte leakage by $26 \%$ and $32 \%$, PPO by $44 \%$ and $47 \%$ and PO by $30 \%$ and 37\% respectively, in PAN3497 and SST806, respectively. However, drought stress decreased proline content by $20 \%$ and $24 \%$, oxidative damage to lipids measured as malondialdehyde by $34 \%$ and $60 \%$, and total phenol content by $55 \%$ and $40 \%$ respectively, in AM treated plants of PAN3497 and SST806. PAN3497 was generally more drought-sensitive than SST806. This study showed that AM can contribute to protect plants against drought stress by alleviating water deficit induced oxidative stress.
\end{abstract}

Keywords: bread wheat; arbuscular mycorrhiza; drought stress; morphological traits; physiological traits; antioxidants

\section{Introduction}

Drought stress is the single largest abiotic stress factor leading to reduced cereal (rice, wheat and maize) yields [1]. In 2013, approximately 65 million ha of wheat was affected by drought stress [2]. The impact of drought on wheat productivity is becoming increasingly important in the world, as wheat represents a large proportion of total consumed calories in most populated regions $[3,4]$. Yield potential is highly variable due to differences in the timing and intensity of stress in the growing cycle [5]. Grain yield of wheat has been reported to decline by as much as 60\% because of drought stress [6].

Adaptation of crops to water deficit is crucial, especially in a climate change scenario [7]. To tolerate abiotic stress, plants have many adaptation strategies. In this context, many studies focused on ways to secure food production in the future [8]. It was reported that plants cope with drought stress by developing drought avoidance and/or drought tolerance mechanisms, which include osmotic adjustment, regulation of stomatal conductance and photosynthesis, production of antioxidant and scavenger compounds, or regulation of water uptake and flow in their tissues $[9,10]$.

It is clear that knowledge on crop responses to water deficit, and the mechanisms of drought tolerance is still limited [11]. Previous studies on drought tolerance in maize and 
other crops have shown tolerant cultivars with significant differences in antioxidant activity, presented as lower lipid peroxidation, improved accumulation of osmolytes and turgor adjustment, maintained photosynthetic activity and regulated enzymatic activities [11,12], whereas a few other studies focused on the effect of micro-organisms, like bacteria and fungi, on this constraint [13].

In this context, the symbiosis of arbuscular mycorrhiza (AM) fungi with plant roots has been shown to be helpful to tolerate and overcome water stress episodes in different plant species [14,15], including wheat [16]. It was previously reported that AM-plant association leads to better plant antioxidant activity, osmotic regulation, and root hydraulic properties [17]. Also, AM inoculated plants generally present a higher level of photosynthetic pigments, enhanced chlorophyll fluorescence traits and net photosynthetic rate [18], as well as different hormone regulation compared to control plants [19]. Symbiosis with mycorrhiza enhanced host plant tolerance to drought stress due to complex adaptations, including morphology, growth, and metabolism. The main consequences of this adaptation are a decrease of cell division and expansion, leaf size, stem elongation, and root proliferation, and disturbed stomatal oscillations, plant water, and nutrient relations [16,20].

It has been suggested that mycorrhiza colonization has a host-dependent plant colonization effect, which varies between plant species and genotypes [21]. Variation in plant response to AM inoculation exists for different wheat cultivars under drought stress [22]. The present study investigated the effect of AM inoculation on bread wheat cultivars under drought stress conditions for morphological, physiological, and oxidative metabolism changes. Therefore, the aim of this study was to determine the effect of AM inoculation on (a) the extent of regulation of various antioxidants and metabolites, and (b) the morphological traits in bread wheat cultivars in the presense and absence of drought stress. The hypothesis is that AM inoculation could improve drought tolerance in wheat.

\section{Results}

\subsection{Plant Growth}

Throughout the growth period, drought stress differentially affected all traits. There was a significant increase in all the studied traits of every treatment, except for length of the last node for PAN3497 after 15 days of drought stress application. The decrease of length of the last node was around 70\% for both treatments (T2 and T3). SST806 was more tolerant to drought stress than PAN3497 for all characteristics except for the length of the last node (Table 1). AM ameliorated all growth parameters of the two cultivars after 15, 30 and 45 days of stress application (T3). The highest amelioration was noted for leaf number after 45 days of stress, where the increase was 35\% and 39\% for PAN3497 and SST806, respectively. In addition, increase of tiller number due to mycorrhiza under drought stress was $38 \%$ and $45 \%$, respectively (Table 1 ).

\subsection{Chlorophyll Content}

Drought stress (T2) reduced leaf chlorophyll content of both cultivars between $50 \%$ and $60 \%$ (Figure 1). Under the same conditions, this trait was also reduced in the AM treatment by $55.5 \%$ and $60 \%$, respectively, for SST806 and PAN3497. Plants inoculated with AM exhibited the highest total chlorophyll content in both cultivars (Figure 1). Under drought stress conditions, plants inoculated with AM (T3) showed an increase of this trait compared to non-inoculated plants (T2). This increase was higher in PAN3497 (Figure 1). 
Table 1. Effect of drought stress on morphological characteristics in two bread wheat cultivars with different mycorrhizal treatments, grown under greenhouse conditions.

\begin{tabular}{|c|c|c|c|c|c|c|c|c|c|c|c|c|c|c|c|}
\hline \multirow{6}{*}{ No stress application } & \multicolumn{3}{|c|}{ PL (cm) } & \multicolumn{2}{|c|}{ TN Plant $^{-1}$} & \multicolumn{2}{|c|}{ NN Tiller-1 } & \multicolumn{2}{|c|}{$\operatorname{LLN}(\mathrm{cm})$} & \multicolumn{2}{|c|}{ LN Plant ${ }^{-1}$} & \multicolumn{2}{|c|}{$\mathrm{LL}(\mathrm{cm})$} & \multicolumn{2}{|c|}{$\mathrm{LW}(\mathrm{cm})$} \\
\hline & & PAN3497 & SST806 & PAN3497 & SST806 & PAN3497 & SST806 & $\begin{array}{ll}\text { PAN3497 } \\
\end{array}$ & SST806 & PAN3497 & SST806 & PAN3497 & SST806 & PAN3497 & SST806 \\
\hline & т0 & $23.06 \pm 2.7^{b}$ & $21.92 \pm 2.9^{\mathrm{c}}$ & $1.46 \pm 0.63^{\mathrm{C}}$ & $1.53 \pm 0.6^{b}$ & $1.66 \pm 0.4 \mathrm{~b}$ & $1.2 \pm 0.41^{\mathrm{c}}$ & $1.44 \pm 0.8^{\mathrm{b}}$ & $1.71 \pm 0.77 \mathrm{~b}$ & $3.93 \pm 1.09 \mathrm{~b}$ & $4.6 \pm 2.04 \mathrm{~b}$ & $20.14 \pm 2.04 \mathrm{~b}$ & $18.21 \pm 2.67^{\mathrm{c}}$ & $0.58 \pm 0.13$ & $0.58 \pm 0.15$ \\
\hline & $\mathrm{T} 1$ & $28.60 \pm 2.02 \mathrm{a}$ & $25.4 \pm 1.99 \mathrm{a}$ & $2.26 \pm 0.45 \mathrm{a}$ & $1.8 \pm 0.41 \mathrm{ab}$ & $2 \pm 0.53^{\mathrm{a}}$ & $2.06 \pm 0.45 \mathrm{a}$ & $2.12 \pm 0.60 \mathrm{a}$ & $2.26 \pm 0.66^{\mathrm{a}}$ & $6.46 \pm 1.40^{\mathrm{a}}$ & $5.6 \pm 1.05 \mathrm{a}$ & $23.06 \pm 1.7^{\mathrm{a}}$ & $19.8 \pm 1.8^{\mathrm{a}}$ & $0.76 \pm 0.11$ & $0.71 \pm 0.09$ \\
\hline & T2 & $23.06 \pm 1.6^{b}$ & $22.46 \pm 0.87^{c}$ & $1.46 \pm 2.05^{\mathrm{c}}$ & $2 \pm 0.23 \mathrm{a}$ & $1.66 \pm 0.48 \mathrm{~b}$ & $1.2 \pm 0.42^{\mathrm{C}}$ & $1.58 \pm 0.76^{\mathrm{b}}$ & $1.54 \pm 0.72^{\mathrm{C}}$ & $3.73 \pm 1.27 \mathrm{~b}$ & $4.93 \pm 1.90 \mathrm{~b}$ & $19.73 \pm 1.89^{c}$ & $18.16 \pm 1.77^{\mathrm{c}}$ & $0.58 \pm 0.10$ & $0.58 \pm 0.13$ \\
\hline & тз & $28 \pm 1.2^{\mathrm{a}}$ & $23.13 \pm 2.4 \mathrm{~b}$ & $1.96 \pm 1.98 \mathrm{~b}$ & $2 \pm 0.50 \mathrm{a}$ & $2 \pm 0.38^{\mathrm{a}}$ & $1.86 \pm 0.40 \mathrm{~b}$ & $2.12 \pm 0.66 \mathrm{a}$ & $1.91 \pm 0.66 \mathrm{ab}$ & $6.06 \pm 1.10^{\mathrm{a}}$ & $4.86 \pm 1.94 \mathrm{~b}$ & $23.06 \pm 2.00 \mathrm{a}$ & $18.73 \pm 2.08 \mathrm{~b}$ & $0.76 \pm 0.08$ & $0.66 \pm 011$ \\
\hline \multirow{6}{*}{$\begin{array}{l}15 \text { days after } \\
\text { stress application }\end{array}$} & \multicolumn{3}{|c|}{ PL (cm) } & \multicolumn{2}{|c|}{ TN Plant $^{-1}$} & \multicolumn{2}{|c|}{$\mathrm{NN}$} & \multicolumn{2}{|c|}{ LLN (cm) } & \multicolumn{2}{|c|}{ LN } & \multicolumn{2}{|c|}{ LL (cm) } & \multicolumn{2}{|c|}{$\mathrm{LW}(\mathrm{cm})$} \\
\hline & & PAN3497 & SST806 & $\begin{array}{ll}\text { PAN3497 } \\
\end{array}$ & SST806 & PAN3497 & SST806 & PAN3497 & SST806 & PAN3497 & SST806 & PAN3497 & SST806 & PAN3497 & SST806 \\
\hline & то & $35.2 \pm 3.9^{\mathrm{a}}$ & $32.6 \pm 2.7^{\mathrm{a}}$ & $2.53 \pm 0.63^{\mathrm{b}}$ & $3 \pm 0.84 \mathrm{~b}$ & $2.6 \pm 0.50 \mathrm{~b}$ & $2.26 \pm 0.45^{\mathrm{c}}$ & $2.42 \pm 1.2 \mathrm{~b}$ & $2.033 \pm 0.97 \mathrm{a}$ & $8.86 \pm 1.7^{\mathrm{b}}$ & $11.13 \pm 3.5 \mathrm{ab}$ & $26.13 \pm 2.3 \mathrm{a}$ & $25.46 \pm 1.7 \mathrm{a}$ & $0.86 \pm 0.13 \mathrm{~b}$ & $0.86 \pm 0.11^{\mathrm{a}}$ \\
\hline & $\mathrm{T} 1$ & $34.53 \pm 3.02 \mathrm{a}$ & $31.37 \pm 2.3^{b}$ & $3.46 \pm 0.99 \mathrm{a}$ & $3.4 \pm 0.6^{\mathrm{a}}$ & $2.46 \pm 0.51 \mathrm{~b}$ & $2.73 \pm 0.45$ a & $2.67 \pm 0.79 \mathrm{a}$ & $1.63 \pm 0.69 \mathrm{~b}$ & $11.33 \pm 2.7^{\mathrm{a}}$ & $11.86 \pm 1.8^{\mathrm{a}}$ & $26.06 \pm 2.3^{\mathrm{a}}$ & $25 \pm 1.8^{\mathrm{a}}$ & $0.97 \pm 0.14 \mathrm{a}$ & $0.78 \pm 0.08 \mathrm{~b}$ \\
\hline & T2 & $27.86 \pm 3.2^{c}$ & $25.93 \pm 2.5 \mathrm{~d}$ & $1.66 \pm 0.72^{\mathrm{c}}$ & $2.06 \pm 0.96^{\mathrm{c}}$ & $2.8 \pm 0.41^{\mathrm{a}}$ & $2.4 \pm 0.50^{b}$ & $0.73 \pm 0.36^{\mathrm{c}}$ & $1.47 \pm 0.78 \mathrm{~b}$ & $5.93 \pm 1.9^{c}$ & $7.26 \pm 2.08^{c}$ & $22.06 \pm 2.7 \mathrm{~b}$ & $21.13 \pm 2.09 \mathrm{c}$ & $0.62 \pm 0.08 \mathrm{c}$ & $0.70 \pm 0.07 \mathrm{c}$ \\
\hline & $\mathrm{T} 3$ & $28.8 \pm 1.61 \mathrm{~b}$ & $28.53 \pm 4.01^{\mathrm{c}}$ & $1.66 \pm 0.72^{c}$ & $2.8 \pm 0.7 \mathrm{~b}$ & $2.8 \pm 0.41^{\mathrm{a}}$ & $2.26 \pm 0.45^{\mathrm{c}}$ & $0.72 \pm 0.36^{\mathrm{c}}$ & $1.95 \pm 0.90^{\mathrm{a}}$ & $5.93 \pm 1.9^{\mathrm{c}}$ & $9.66 \pm 1.9^{b}$ & $22.06 \pm 2.7^{b}$ & $22.2 \pm 2.8 \mathrm{~b}$ & $0.62 \pm 0.08 \mathrm{c}$ & $0.72 \pm 0.09 \mathrm{~b}$ \\
\hline \multirow{6}{*}{$\begin{array}{l}30 \text { days after } \\
\text { stress application }\end{array}$} & \multicolumn{3}{|c|}{ PL (cm) } & \multicolumn{2}{|c|}{ TN Plant $^{-1}$} & \multicolumn{2}{|c|}{$\mathrm{NN}$} & \multicolumn{2}{|c|}{$\operatorname{LLN}(\mathrm{cm})$} & \multicolumn{2}{|c|}{ LN } & \multicolumn{2}{|c|}{$\mathrm{LL}(\mathrm{cm})$} & \multicolumn{2}{|c|}{$\mathrm{LW}(\mathrm{cm})$} \\
\hline & & PAN3497 & SST806 & PAN3497 & SST806 & PAN3497 & SST806 & PAN3497 & SST806 & PAN3497 & SST806 & PAN3497 & SST806 & PAN3497 & SST806 \\
\hline & т0 & $38.76 \pm 2.5 \mathrm{a}$ & $33.63 \pm 1.63 \mathrm{~b}$ & $3.43 \pm 0.86^{\mathrm{b}}$ & $4.00 \pm 0.92^{c}$ & $3.3 \pm 0.25$ a & $2.79 \pm 0.51 \mathrm{~b}$ & $1.71 \pm 0.65 \mathrm{bc}$ & $2.38 \pm 0.61 \mathrm{~b}$ & $13.93 \pm 3.6^{b}$ & $17.23 \pm 2.5 \mathrm{~b}$ & $27.06 \pm 2.15$ a & $24.89+1.42 \mathrm{ab}$ & $0.98 \pm 0.11$ a & $0.88+0.10^{b}$ \\
\hline & T1 & $\begin{array}{l}37.43 \pm 2.76 \mathrm{~b} \\
3\end{array}$ & $\begin{array}{l}33.63 \pm 1.63 \mathrm{a} \\
34.52 \pm 3.17 \mathrm{a}\end{array}$ & 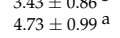 & $\begin{array}{l}4.00 \pm 0.92 \\
5.36 \pm 1.55\end{array}$ & $2.73 \pm 0.25^{\mathrm{c}}$ & $\begin{array}{l}2.79 \pm 0.51 \mathrm{~b} \\
2.86 \pm 0.22 \mathrm{~b}\end{array}$ & $3.035 \pm 1.04 \mathrm{a}$ & $\begin{array}{l}2.38 \pm 0.61^{\mathrm{c}} \\
2.065 \pm 0.64^{\mathrm{s}}\end{array}$ & $\begin{array}{l}1.3935 .6 .6 \mathrm{a} \\
17.66 \pm 4 . \mathrm{a}^{2}\end{array}$ & $\begin{array}{l}1.2 .4 \pm 2.5 \\
19.43 \pm 4.4 a^{\mathrm{a}}\end{array}$ & $26.69 \pm 2.3 \mathrm{ab}$ & $\begin{array}{r}24.89 \pm 1.42 \\
25.5 \pm 2.2^{\mathrm{a}}\end{array}$ & $1.02 \pm 0.17 \mathrm{a}$ & $\begin{array}{l}0.880 .100^{2} \\
0.91 \pm 0.16^{\mathrm{a}}\end{array}$ \\
\hline & T2 & $29.76 \pm 2.3 \mathrm{~d}$ & $28.96 \pm 2.25^{\mathrm{c}}$ & $2.16 \pm 0.61 \mathrm{~d}$ & $2.53 \pm 0.48 \mathrm{~d}$ & $3.40 \pm 0.20 \mathrm{a}$ & $\begin{array}{l}2.86 \pm 0.22 \mathrm{a} \\
3.2 \pm 0.25 \mathrm{a}\end{array}$ & $1.86 \pm 0.68 \mathrm{~b}$ & $\begin{array}{l}2.05050 .04 \\
1.8 \pm 0.69 \mathrm{~d}\end{array}$ & $9.8 \pm 2.2^{\mathrm{d}}$ & $10.63 \pm 2.04 \mathrm{~d}$ & $\begin{array}{l}20.69 \pm 2.3 \\
22.03 \pm 2.2^{\mathrm{c}}\end{array}$ & $21.9 \pm 1.62^{\mathrm{c}}$ & $0.71 \pm 0.09 \mathrm{~b}$ & $0.78 \pm 0.06^{\mathrm{c}}$ \\
\hline & T3 & $31.73 \pm 2.33 \mathrm{c}$ & $31.76 \pm 2.50 \mathrm{bc}$ & $2.99 \pm 1.11 \mathrm{c}$ & $4.23 \pm 0.63 \mathrm{~b}$ & $3.23 \pm 0.49 \mathrm{~b}$ & $2.79 \pm 0.22 \mathrm{~b}$ & $1.64 \pm 0.80^{\mathrm{c}}$ & $2.64 \pm 0.83 \mathrm{a}$ & $12.96 \pm 4.55^{\mathrm{c}}$ & $16.49 \pm 1.2^{\mathrm{c}}$ & $23.69 \pm 2.5^{\mathrm{b}}$ & $24.43 \pm 3.15 \mathrm{~b}$ & $0.86 \pm 0.08^{\circ} \mathrm{b}$ & $0.81 \pm 0.09 \mathrm{~b}$ \\
\hline \multirow{5}{*}{$\begin{array}{l}45 \text { days after } \\
\text { stress application }\end{array}$} & \multicolumn{3}{|c|}{ PL (cm) } & \multicolumn{2}{|c|}{ TN Plant $^{-1}$} & \multicolumn{2}{|c|}{ NN } & \multicolumn{2}{|c|}{ LLN (cm) } & & & & & & \\
\hline & & $\begin{array}{l}\text { PAN3497 } \\
\end{array}$ & SST806 & $\begin{array}{l}\text { PAN3497 } \\
\end{array}$ & SST806 & PAN3497 & SST806 & $\begin{array}{l}\text { PAN3497 } \\
\end{array}$ & SST806 & PAN3497 & SST806 & $\begin{array}{l}\text { PAN3497 } \\
\end{array}$ & SST806 & $\begin{array}{l}\text { PAN3497 } \\
\end{array}$ & SST806 \\
\hline & то & $42.33 \pm 1.17 \mathrm{a}$ & $34.67 \pm 0.57 \mathrm{bc}$ & $4.33 \pm 1.1 \mathrm{~b}$ & $5.00 \pm 1.00^{\mathrm{c}}$ & $4.00 \pm 0.00^{\mathrm{a}}$ & $3.33 \pm 0.57 \mathrm{~b}$ & $1.00 \pm 0.10 \mathrm{~d}$ & $2.73 \pm 0.25 \mathrm{~b}$ & $19.00 \pm 5.5 \mathrm{bc}$ & $23.33 \pm 1.5^{\mathrm{b}}$ & $28.00 \pm 2^{\mathrm{a}}$ & $24.33 \pm 1.15^{b}$ & $1.10 \pm 0.09 \mathrm{a}$ & $0.90 \pm 0.10^{\mathrm{b}}$ \\
\hline & $\mathrm{T} 1$ & $40.33 \pm 2.5 \mathrm{~b}$ & $37.67 \pm 4.04 \mathrm{a}$ & $6.00 \pm 1.00^{a}$ & $7.33 \pm 2.51 \mathrm{a}$ & $3.00 \pm 0.00^{c}$ & $3.00 \pm 0.00^{c}$ & $3.40 \pm 1.30^{\mathrm{a}}$ & $2.50 \pm 0.60 \mathrm{bc}$ & $24.67 \pm 5.5^{\mathrm{a}}$ & $27.00 \pm 7.00 \mathrm{a}$ & $27.33 \pm 2.3 \mathrm{~b}$ & $26.00 \pm 2.6 \mathrm{ab}$ & $1.07 \pm 0.20 \mathrm{ab}$ & $1.04 \pm 0.25^{\mathrm{a}}$ \\
\hline & T2 & $31.67 \pm 1.5 \mathrm{~d}$ & $32.00 \pm 2^{c}$ & $2.67 \pm 0.5^{\mathrm{c}}$ & $3.00 \pm 0.00 \mathrm{~d}$ & $4.00 \pm 0.00 \mathrm{a}$ & $4.00 \pm 0.00 \mathrm{a}$ & $3.00 \pm 1.00 \mathrm{~b}$ & $2.13 \pm 0.60^{c}$ & $13.67 \pm 2.5^{c}$ & $14.00 \pm 2^{c}$ & $22.00 \pm 1.7 \mathrm{~d}$ & $22.67 \pm 1.15^{c}$ & $0.80 \pm 0.10^{b}$ & $0.87 \pm 0.05 \mathrm{~b}$ \\
\hline
\end{tabular}

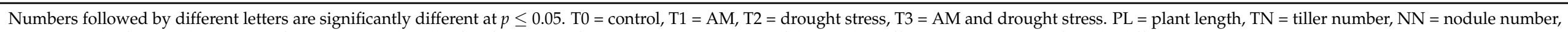

$\mathrm{LLN}=$ length of last node, $\mathrm{LN}=$ Leaf number, $\mathrm{LL}=$ length of leaf, $\mathrm{LW}=$ Leaf width. Values in columns followed by different letters are significantly different at $p \leq 0.05$. 


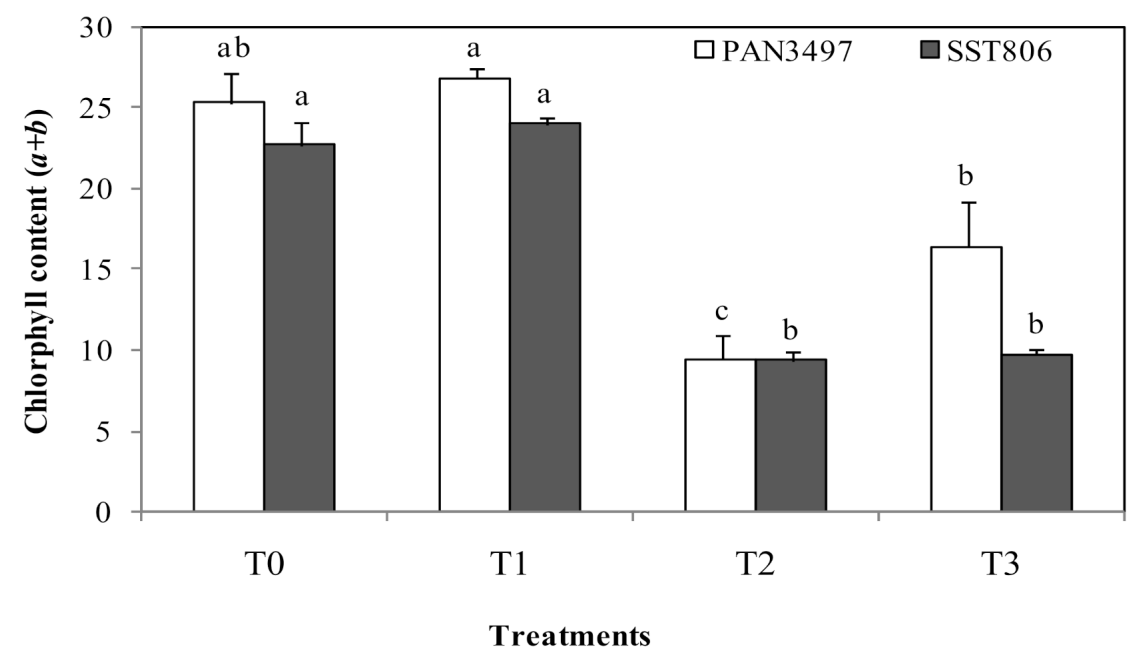

Figure 1. The effect of drought stress on leaf chlorophyll content of two bread wheat cultivars inoculated with arbuscular mycorrhiza and grown under greenhouse conditions. T0: non-inoculated control, T1: plants inoculated with the AM fungus, T2: non-inoculated plants under drought stress and T3: inoculated plants under drought stress. Bars with different letters are significantly different at $p \leq 0.05$.

\subsection{Proline Content}

Drought stress (T2) increased proline content by $28 \%$ and $14 \%$, respectively, for PAN3497 and SST806 (Figure 2). Under drought stress conditions, proline content decreased in the AM-treated cultivars (T3) (33 and 42\% for PAN3497and SST806, respectively).

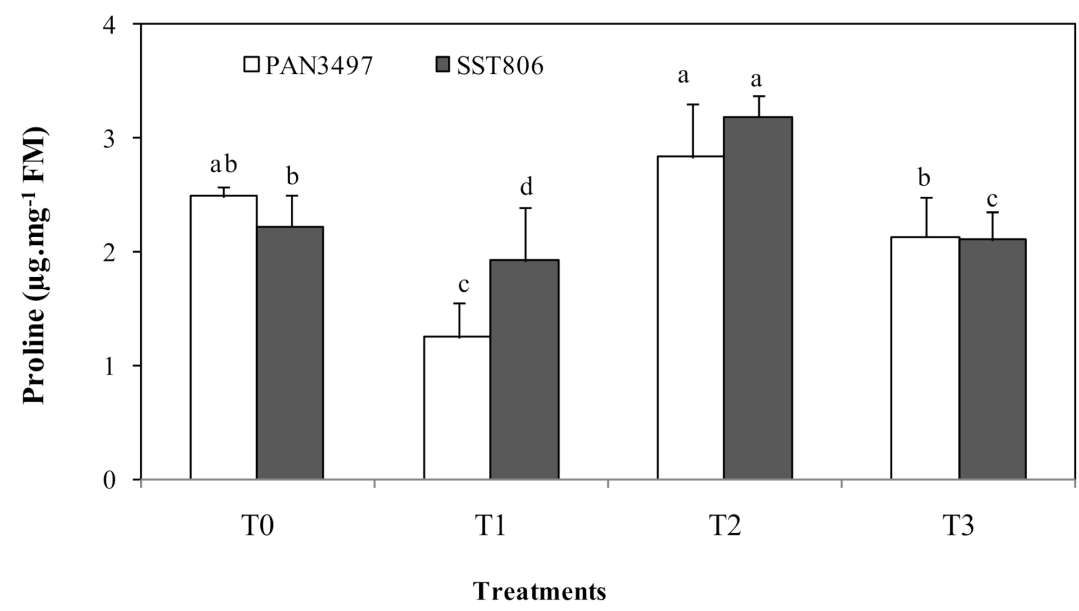

Figure 2. Effect of drought stress on leaf proline content for two bread wheat cultivars inoculated with arbuscular mycorrhiza and grown under greenhouse conditions. T0: non-inoculated control, T1: plants inoculated with the AM fungus, T2: non-inoculated plants under drought stress and T3: inoculated plants under drought stress. Bars with different letters are significantly different at $p \leq 0.05$.

\subsection{Oxidative Damage to Lipids}

Drought stress conditions decreased the oxidative damage to lipids measured as malondialdehyde (MDA) equivalents significantly in both cultivars in comparison with control plants (25\% and $70 \%$ respectively). The oxidative damage to lipids was significantly reduced by drought stress by 34\% and 60\% respectively, for PAN3497 and SST806 in AM-plants, (Figure 3a). 


\subsection{Membrane Electrolyte Leakage and Water Deficit Saturation}

Membrane electrolyte leakage (EL) increased by 30\% and 36\% under drought stress in PAN3497 and SST806, respectively. The AM treatment did not significantly affect this trait (Figure 4a). No significant variability was shown between cultivars due to drought stress (Figure 4a). The EL values were higher in non-AM drought-stressed plants (50\% and 60\% for PAN3497 and SST806) than in AM inoculated drought-stressed plants in both cultivars (40\% and $45 \%$ respectively for PAN3497 and SST806) (Figure 4a). Drought stress did not increase water deficit saturation (WDS) in comparison with control plants (Figure 4b). AM inoculation increased WDS by $6 \%$ and $4 \%$, respectively, in SST806 and PAN3497. AM did not affect WDS under drought stress.

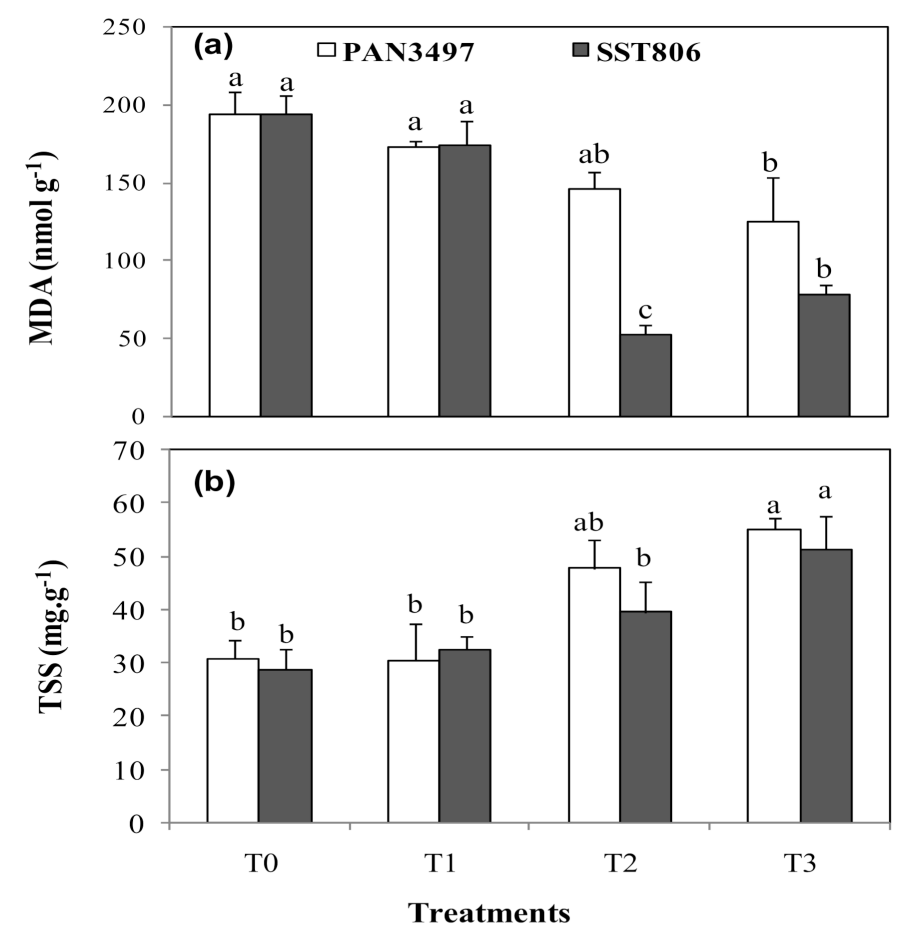

Figure 3. Effect of drought stress on malondialdehyde (MDA) (a) and total soluble sugar (TSS) (b) in the leaves of two bread wheat cultivars inoculated with arbuscular mycorrhiza and grown under green house conditions. T0: non-inoculated control plants, T1: plants inoculated with the AM fungus, T2: non-inoculated plants under drought stress and T3: inoculated plants under drought stress. Bars with different letters are significantly different at $p \leq 0.05$.

\subsection{Total Phenol Content}

Total phenol content in the leaves of the two wheat cultivars under drought stress conditions (T2), was increased the most in SST 806 (44\%). However, with AM inoculation (T3), this trait decreased compared to non-AM inoculation by $60 \%$ and $66 \%$ in PAN3497 and SST806, respectively, under drought stress conditions (Figure 4c). 

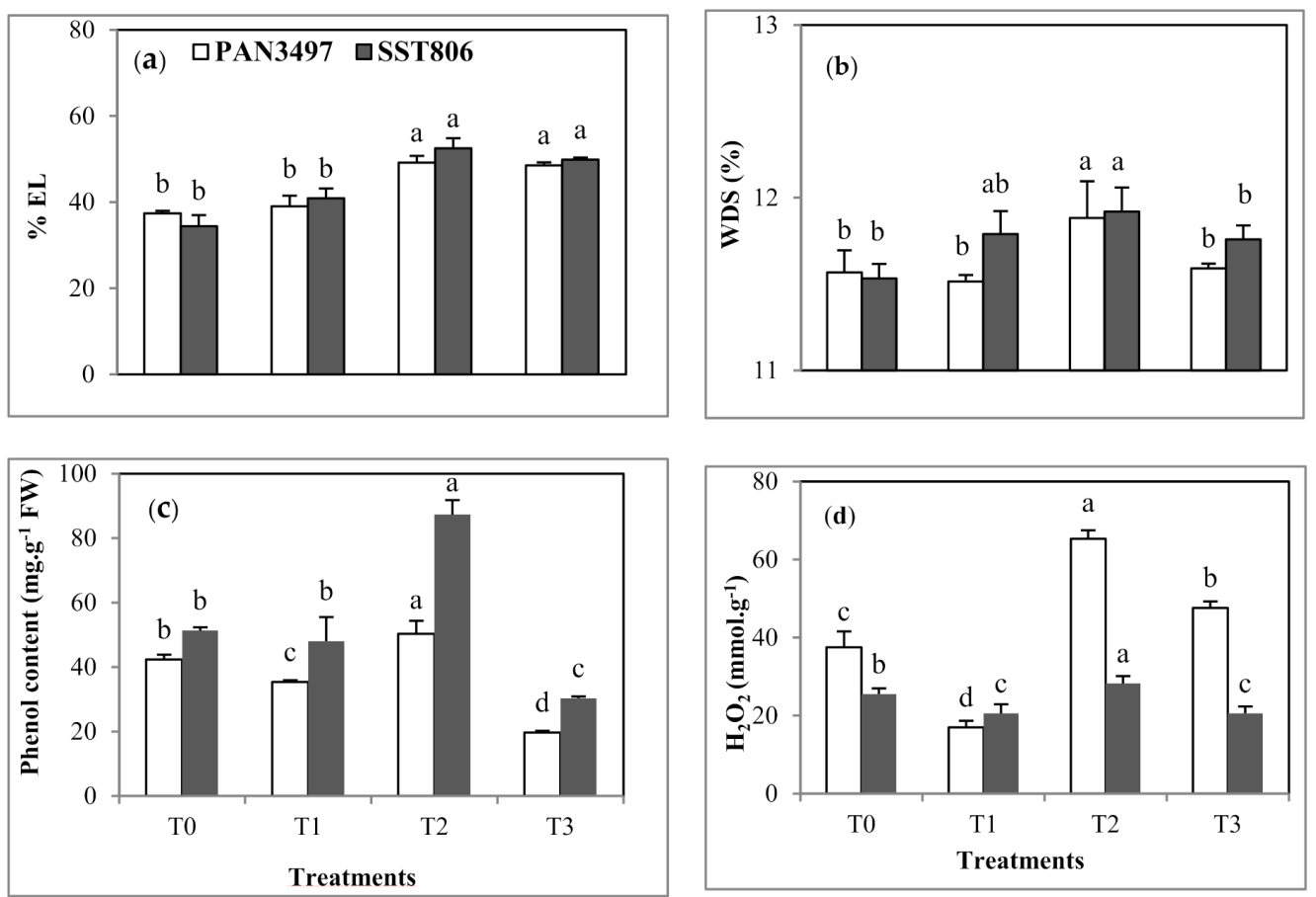

Figure 4. Effect of drought stress on: (a) membrane electrolyte leakage, (b) water deficit saturation, (c) total phenol content and (d) hydrogen peroxide accumulation in the leaves of two bread wheat cultivars inoculated with arbuscular mycorrhiza and grown under greenhouse conditions. T0: noninoculated control plants, T1: plants inoculated with the AM fungus, T2: non-inoculated plants under drought stress and T3: inoculated plants under drought stress. EL: electrolyte leakage, WDS: water deficit saturation. Bars with different letters are significantly different at $p \leq 0.05$.

\subsection{Accumulation of Hydrogen Peroxide}

The accumulation of hydrogen peroxide $\left(\mathrm{H}_{2} \mathrm{O}_{2}\right)$ was significantly affected by AM inoculation (T1), increasing the values in AM plants under drought stress conditions (T3) (47\% and $16 \%$ for PAN3497 and SST 806) (Figure 4d). Under drought stress conditions, $\mathrm{H}_{2} \mathrm{O}_{2}$ accumulation was higher in non-AM PAN3497 $\left(70 \mathrm{mmol} \mathrm{g}^{-1}\right)$ plants than in non-AM SST 806 plants ( $30 \mathrm{mmol} \mathrm{g}^{-1}$ ) (Figure $4 \mathrm{~d}$ ).

\subsection{Peroxidase and Polyphenol Oxidase Activities}

The peroxidase (PO) in leaves was on the order of $4 \mu \mathrm{mol} \mathrm{g}^{-1} \mathrm{FM}$ in both cultivars under drought stress conditions (T2). With AM inoculation (T1), PO varied significantly by $30 \%$ and 37\%, respectively, in PAN3497 and SST806 compared to the control treatment (T0) (Figure 5a). In general, drought stress (T2) did not significantly affect PO activity. However, the polyphenol oxidase (PPO) activity was increased under the same conditions (T2) (44\% and $47 \%$, respectively). It exceeded $16 \mu \mathrm{mol} \mathrm{g}{ }^{-1} \mathrm{FM}$ in the leaves of SST 806. In the AM-treatment, PPO was increased under stress conditions (T3) for both cultivars compared to the control (T1) (Figure 5b). 


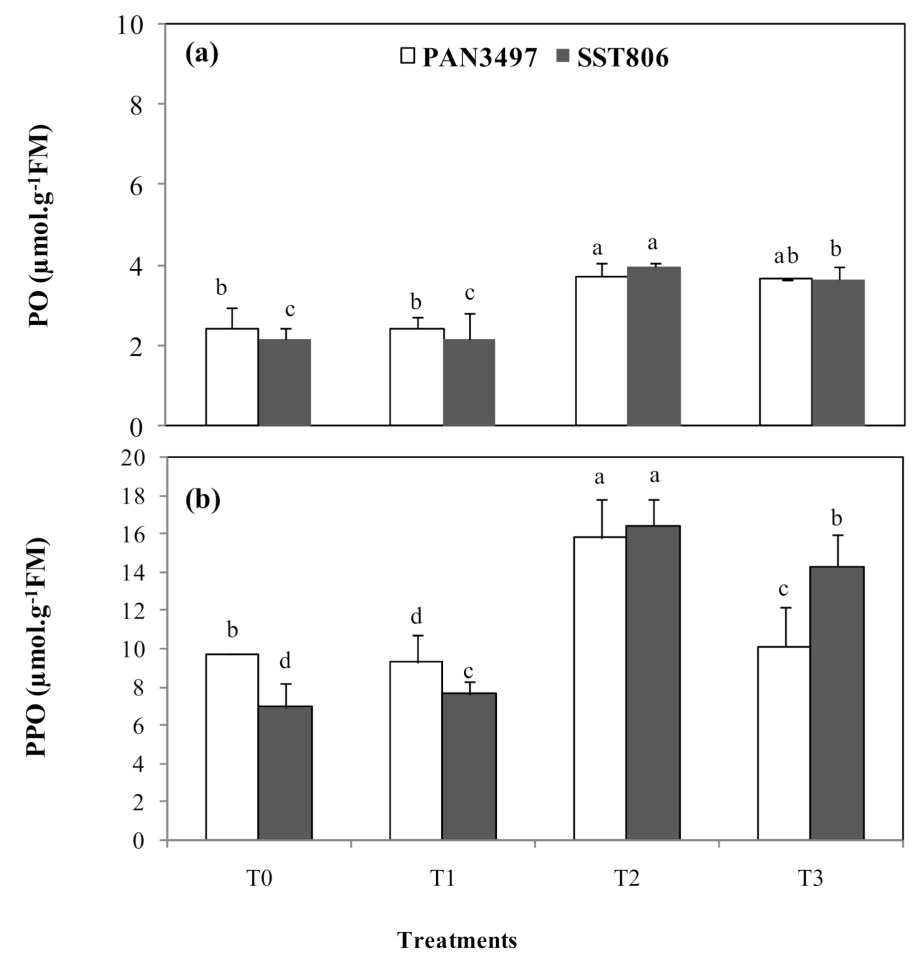

Figure 5. Effect of drought stress on peroxidase (PO) (a) and polyphenol oxidase (PPO) (b) activities in the leaves of two bread wheat cultivars inoculated with arbuscular mycorrhiza and grown under greenhouse conditions. T0: non-inoculated control plants, T1: plants inoculated with the AM fungus, T2: non-inoculated plants under drought stress and T3: inoculated plants under drought stress. Bars with different letters are significantly different at $p \leq 0.05$.

\section{Discussion}

The current study, along with previous studies [17] highlighted the divergent responses to AM inoculation of different bread wheat cultivars under drought stress conditions. Drought significantly decreased morphological and physiological traits in the two cultivars under both mycorrhiza inoculated and non-inoculated conditions [23]. Inoculation with AM enhanced the water absorption in many of the plants that were subjected to drought stress. AM fungus mycelia can penetrate a larger volume of soil than the host plant roots, therefore increasing water absorption and transport to the roots and other plant parts, resulting in reduced drought stress [24]. Inoculation with the AM fungus significantly influenced morphological traits, increasing mostly leaf and tiller number per plant. This confirmed the efficiency of the applied spore density and AM subspecies used in this study. These findings agree with those from a study [25] reporting a higher tiller number in mycorrhiza treated wheat. Another study [26] reported that many plants treated with AM had increases in different agronomic traits compared to those that were not treated.

In comparison with the plants that were not inoculated, the AM plants showed the highest increase of leaf number, which was 35\% and 39\% for PAN3497 and SST806, respectively. AM inoculation has been previously reported to enhance drought tolerance of host plants [27]. In the present study, the beneficial effect of the AM fungus under drought stress was observed in leaf and tiller number. Indeed, plant biomass production is an integrative index of plant performance under stress conditions and the efficiency of the AM symbiosis has often been measured in terms of host plant biomass improvement [9].

AM inoculation also improved photosynthetic capacity of leaves [28]. Total chlorophyll content was affected by drought stress. These results confirmed those of previous studies $[29,30]$ where leaf photosynthetic capacity was negatively influenced by water deficit conditions, resulting in chloroplast dehydration. Regarding the effect of AM inoc- 
ulation, the amount of Chl $a$ and $b$ in leaves was ameliorated in the AM-treated cultivars compared to those that were not treated. Higher concentrations of total Chl in inoculated cultivars indicated the positive effect of inoculation that stimulated increased photosynthesis under both stress and non-stress conditions, mostly in PAN3497.

Plants have evolved complex mechanisms allowing for adaptation to water deficits under drought stress. In this study, lower water deficit saturation of the inoculated plants under water stress conditions is probably due to increased water uptake mediated by mycorrhizal hyphae that can induce some cellular changes in plants. This agrees with previous findings [23]. In leaves, high EL was generally noticed under drought stress, accompanied by a significant increase of total phenol secretion and accumulation of $\mathrm{H}_{2} \mathrm{O}_{2}$ as evidence of plant physiological reaction to stress conditions.

The percentage of membrane EL, an indicator of cell membrane stability, has been identified as a good indicator of the tolerance to water stress [30,31]. Accordingly, non-AM inoculated drought-tolerant plants had lower EL values than the corresponding droughtsensitive ones. However, under drought stress, the two cultivars maintained variable values of EL, total phenols and $\mathrm{H}_{2} \mathrm{O}_{2}$. Interestingly, except for total phenol secretion, AM increased EL, WDS and $\mathrm{H}_{2} \mathrm{O}_{2}$ under drought compared to the controls in both cultivars. Similarly, it was reported [31,32] that AM symbiosis regulated different physiological mechanisms under drought stress in bread wheat.

Plants also evolved to regulate compatible solutes like proline and TSS, termed as drought escape [33]. However, proline accumulation in drought stressed plants vary and depend on cultivar and treatment. AM inoculation increased this trait under drought stress (T3) compared to the AM inoculated treatment without stress (T1). It was also found that TSS concentration was significantly increased by the AM inoculation in both bread wheat cultivars under drought stress conditions. This agrees with previous findings that demonstrated that the AM fungi improve the plant osmotic adjustment by accumulation of different compounds (such as sugars, proline and free amino acids) [34,35]. This regulation by the AM symbiosis has been proposed as a mechanism allowing plants to grow under water stress [36]. In leaves of drought stressed plants, AM inoculated plants had increased TSS in both cultivars. The key effect of AM on sugar accumulation has been reported under drought conditions in various studies $[19,36,37]$ as was also shown here in bread wheat. In addition, AM inoculation was shown as an alternative to escape drought stress conditions. In this sense, the higher membrane stability is often related to lower MDA levels [38] because of lipid peroxidation. These results agree with previous studies where MDA production was reduced by AM fungi [39]. Results in the current study showed that AM symbiosis decreased MDA accumulation under drought stress.

AM inoculated plants regulate some enzymatic activities as an adaptation strategy during drought stress episodes. These activities are stimulated in AM inoculated plants more than in non-inoculated plants [40]. Among these activities, this study focused on PO and PPO reaction under drought stress. In AM inoculated plants, the PO and PPO increased under stress conditions (T3) for both cultivars compared to the AM inoculated non-drought treatment (T1). These results confirmed those reported on AM-inoculated tomato under salt stress [41]. Activity of antioxidant defense enzymes was largely induced by AM-inoculation in tomato plants. Oxidative burst and generation of superoxide radicals occur during development of hypersensitive response in plant-stress interactions [42,43].

\section{Materials and Methods}

\subsection{Soil and Biological Materials and Trial Layout}

The experiment was carried out in a greenhouse at the University of Free State, Bloemfontein, South Africa. Two commercial, hard red spring wheat cultivars with excellent bread making quality and yield were used in the study (PAN3497 and SST806). These cultivars both have a medium growing period. They are the products of two different seed companies. Nothing is known about their root systems, but they are similar morphologically. The soil had a pH of 6.8 and comprised of $50 \%$ sand, $10 \%$ silt and $40 \%$ clay. Three seeds 
were planted per pot filled with $2 \mathrm{~kg}$ soil sterilized and fertilized with $7.5 \mathrm{mg} \mathrm{kg}^{-1}(\mathrm{P})$, $231.4 \mathrm{mg} \mathrm{kg}^{-1}(\mathrm{~K}), 564 \mathrm{mg} \mathrm{kg}^{-1}(\mathrm{Ca}), 147.6 \mathrm{mg} \mathrm{kg}^{-1}(\mathrm{Mg})$. Mycorrhiza inoculum (commercial inoculum in powder form, registered and produced by Biocult (Pty) Ltd 005333/07, Somerset West, South Africa) was used as bio-inoculant as a seed application of $150 \mathrm{~g}$ per $150 \mathrm{~kg}$ of seed. Thirty minutes before sowing, seeds were mixed very well with the mycorrhiza inoculant. The active ingredient was mycorrizae subspecies, 400 spores per gram (as indicated by the manufacturer). The subspecies included Glomus mosseae, Glomus intraradices, Glomus etunicatum, and Scutellospora dipurpurescens. The experimental design was a randomized complete block design with two factors: (1) inoculation treatment and (2) drought stress application. The different combinations of these factors gave a total of four treatments for each cultivar which were non-inoculated control plants (T0), plants inoculated with the AM fungus (T1), non-inoculated plants under drought stress (T2) and inoculated plants under drought stress (T3). Three replicates were used for each treatment with 15 plants per replication, giving a total of 45 plants per treatment.

\subsection{Growing Conditions}

The experiment was conducted from May 2019 in the greenhouse. The growing period was 6 months under temperatures set to $19 / 25^{\circ} \mathrm{C}$ night/day, with a relative humidity of $60-70 \%$. Soil moisture was measured with a soil meter (Efekto Ltd., Caledon, South Africa). Water was supplied daily to maintain soil moisture at $100 \%$ field capacity during the first 4 weeks after sowing. At three-leaf stage, drought stress was applied and plants under stress were allowed to dry out until soil water content reached $25 \%$ field capacity, while the non-stressed treatments were maintained at 100\% field capacity. The soil water content was measured daily with the soil meter before rewatering (late afternoon), reaching a minimum soil water content around $25 \%$ field capacity in the drought-stressed treatments [7].

\subsection{Measurements}

\subsubsection{Morphological Measurements}

Morphological traits measured were plant length $(\mathrm{cm})$, tiller number per plant, node number per tiller, length of the last node $(\mathrm{cm})$ and leaf number per plant. Leaf length $(\mathrm{cm})$ and leaf width $(\mathrm{cm})$ were measured for all treatments before drought stress application and then 15, 30 and 45 days after drought stress application. Absorbance measurements for all treatments were done using a Jenway 7315 spectrophotometer (Cole-Parmer, Staffordshire, UK).

\subsubsection{Total Chlorophyll Content}

Total chlorophyll content was measured using methods described previously [44,45]. It was extracted with acetone in a mortar, using $200 \mathrm{mg}$ of fresh leaf tissue and $5 \mathrm{~mL}$ of acetone $(80 \%, v / v)$. Total chlorophyll content was measured after centrifugation $(10 \mathrm{~min}$ at $5000 \times \mathrm{g})$; the absorbance of the supernatant was measured at 663 and $645 \mathrm{~nm}$. Chlorophyll concentration was calculated using the following formula Equation (1):

$$
\text { Total Chlorophyll }=8.02 \mathrm{OD}_{663}+20.20 \mathrm{OD}_{645} \text {. }
$$

\subsubsection{Proline Content}

Proline content was measured using methods described previously [46,47]. It was extracted from leaf samples (100 mg FW) with $2 \mathrm{~mL}$ of $40 \%$ methanol:water. The tubes were incubated in a water bath at $85^{\circ} \mathrm{C}$ for $30 \mathrm{~min}$, then $1 \mathrm{ml}$ of extract was mixed with $1 \mathrm{~mL}$ of a mixture of glacial acetic acid and orthophosphoric acid (6 M) $(3: 2 ; v / v)$ and $25 \mathrm{mg}$ ninhydrin. After $1 \mathrm{~h}$ of incubation at $100{ }^{\circ} \mathrm{C}$, the reaction was terminated in an ice bath to stabilize the purple color of the extract, then $5 \mathrm{~mL}$ of toluene was added to each tube and the absorbance of top purple aqueous layer was measured at $528 \mathrm{~nm}$ with a spectrophotometer. The proline concentration was determined according to the standard curve obtained using reference proline solutions. 


\subsubsection{Total Soluble Sugar}

Total soluble sugars were extracted from $100 \mathrm{mg}$ of fresh leaf tissues in $100 \mathrm{mM}$ potassium phosphate buffer ( $\mathrm{pH}$ 7). Soluble sugars were analyzed from $0.025 \mathrm{~mL}$ of plant extract reacting with $3 \mathrm{~mL}$ of freshly prepared anthrone (200 $\mathrm{mg}$ anthrone, $100 \mathrm{~mL} \mathrm{72 \%}$ $\left.(v / v) \mathrm{H}_{2} \mathrm{SO}_{4}\right)$ and placed in a boiling water bath for $10 \mathrm{~min}$. After cooling, the absorbance at $620 \mathrm{~nm}$ was determined. The calibration curve was drawn using glucose in the range of 0.2 to $0.4 \mathrm{mg} \mathrm{mL}^{-1}[48,49]$.

\subsubsection{Oxidative Damage to Lipids}

Lipid peroxidation was estimated as the content of TBA-reactive substances (TBARS) and expressed as equivalents of MDA [50,51]. Lipid peroxides were extracted by grinding $100 \mathrm{mg}$ of fresh leaf tissues with an ice-cold mortar and $6 \mathrm{~mL}$ of $100 \mathrm{mM}$ potassium phosphate buffer ( $\mathrm{pH} 7$ ). Homogenates were filtered through one Miracloth layer and centrifuged at $15,000 \times \mathrm{g}$ for $20 \mathrm{~min}$. The chromogen was formed by mixing $200 \mathrm{~mL}$ of supernatants with $1 \mathrm{~mL}$ of a reaction mixture containing $15 \%(w / v)$ trichloroacetic acid (TCA), $0.375 \%(w / v)$ 2-thiobarbituric acid (TBA), $0.1 \%(w / v)$ butylated hydroxytoluene, $0.25 \mathrm{~N} \mathrm{HCl}$ and by incubating the mixture at $100{ }^{\circ} \mathrm{C}$ for $30 \mathrm{~min}$. After cooling at room temperature, tubes were centrifuged at $800 \times g$ for $5 \mathrm{~min}$ and the supernatant was used for spectro-photometric reading at $532 \mathrm{~nm}$. The calibration curve was drawn using MDA in the range of $0.1-10 \mathrm{nmol}$.

\subsubsection{Water Deficit Saturation}

Water deficit saturation (WDS) was determined by weighing $100 \mathrm{mg}$ (FW) young leaf tissue into a Petri dish and keeping it in distilled water $(3 \mathrm{~mL})$ for $24 \mathrm{~h}$, thereafter weighing it again (turgid weight: TW). Finally, the leaves were dried for $72 \mathrm{~h}$ at room temperature and then weighed (dry weight: DW) again. WDS was calculated [47] as follows Equation (2):

$$
\operatorname{WDS}(\%)=(\mathrm{TW} / \mathrm{FW}) /(\mathrm{TW}-\mathrm{DW}) \times 100
$$

\subsubsection{Electrolyte Leakage}

Membrane permeability (electrolyte leakage, EL) was employed to evaluate the stability of the cell membrane. The EL and the electrical conductivity are related to the EC [47,52]. The electrolyte leakage is expressed as EL $(\%)=(\mathrm{EC} 1 / \mathrm{EC} 2) \times 100$, where EC1 and EC2 denote the obtained values from incubated leaves at $25^{\circ} \mathrm{C}$ for one day and that measured for autoclaved leaves at $120^{\circ} \mathrm{C}$ for $20 \mathrm{~min}$, respectively.

\subsubsection{Hydrogen Peroxide Content}

Hydrogen peroxide content was determined according to published methods $[53,54]$. A $100 \mathrm{mg}$ of leaf sample aliquot was centrifuged at $15,000 \times \mathrm{g}$ at $4{ }^{\circ} \mathrm{C}$ for $15 \mathrm{~min}$ after grinding it in $2 \mathrm{~mL}$ of TCA (20\%). The supernatants of these extracts were collected to determine their $\mathrm{H}_{2} \mathrm{O}_{2}$ content. To $0.5 \mathrm{~mL}$ of the extract, $0.5 \mathrm{~mL}$ of potassium phosphate buffer $(10 \mathrm{mM}, \mathrm{pH} 7)$ was added. One $\mathrm{mL}$ of potassium iodine $(1 \mathrm{M})$ was added after incubating this for an hour in the dark. $\mathrm{H}_{2} \mathrm{O}_{2}$ content was expressed in $\mu$ mol per $g$ of fresh weight (FW). $\mathrm{H}_{2} \mathrm{O}_{2}$ content was determined using a standard curve established under the same conditions with known concentrations of the $\mathrm{H}_{2} \mathrm{O}_{2}$ range.

\subsubsection{Total Phenol Content}

Total phenol content was measured on fresh leaves $(100 \mathrm{mg})$ that were ground at $4{ }^{\circ} \mathrm{C}$ in $80 \%$ methanol using an ice-cold mortar. The homogenate was centrifuged for $3 \mathrm{~min}$. Total phenol content was estimated on the supernatants based on the Folin-Ciocalteu method $[55,56]$. The absorption was determined at $760 \mathrm{~nm}$. A calibration curve was constructed from freshly prepared solutions of $(+)$-catechin. The results were calculated as mg of catechin per g FW [56]. 


\subsubsection{Polyphenol Oxidase and Peroxidase Content}

To prepare the enzyme extract of polyphenol oxidase (PPO) and peroxidase (PO), the reaction mixture consisted of $200 \mu \mathrm{L}$ of $\mathrm{H}_{2} \mathrm{O}_{2}$ at $0.3 \%, 300 \mu \mathrm{L}$ of guaiacol at $20 \mathrm{mM}$, $2 \mathrm{~mL}$ of phosphate buffer $(0.1 \mathrm{M}, \mathrm{pH} 6), 1 \mathrm{~mL}$ of distilled water and $50 \mu \mathrm{L}$ of enzymatic extract. PO activity was determined from the decomposition of $\mathrm{H}_{2} \mathrm{O}_{2}$ at $470 \mathrm{~nm}$. For the PPO activity assay [54,57], the reaction mixture consisted of $500 \mu \mathrm{L}$ catechol at $1.6 \%$ in phosphate buffer $(0.1 \mathrm{M}, \mathrm{pH} 6), 250 \mu \mathrm{L}$ of distilled water, $200 \mu \mathrm{L}$ of phosphate buffer $(0.1 \mathrm{M}, \mathrm{pH} 6)$ and $100 \mu \mathrm{L}$ of enzymatic extract. Thereafter, the absorbance was recorded at $410 \mathrm{~nm}$. For both enzymes, reading of the optical density was checked once every $60 \mathrm{~s}$ during the $3 \mathrm{~min}$ of incubation against a control, where the enzymatic extract was replaced by distilled water. Enzyme activities were expressed as the amount of protein decomposing $1 \mu \mathrm{mol}$ of $\mathrm{H}_{2} \mathrm{O}_{2}$ per $\mathrm{g} F W$.

\subsection{Data Analysis}

Analysis of variance (ANOVA) was performed using the SPSS statistical program v.13 (IBM Corporation, Armonk, New York, NY, USA) (http:/ / oss.software.ibm.com/icu4j/ accessed on 1 February 2021), and subsequent comparison of means was done using Duncan's multiple-range test at $p=0.05$.

\section{Conclusions}

The current study showed that AM can contribute to protect plants against drought stress by alleviating the water deficit induced oxidative stress. Enhanced antioxidant enzyme activity and lower lipid per-oxidation with AM inoculation may contribute to better maintenance of the physiological reactions in plant under drought stress. AM contribution varied significantly between the two cultivars under drought stress conditions. Overall, SST806 was more tolerant than PAN3497 to drought stress. The reason for this is not clear, as these cultivars have similar morphological characteristics, but this should be investigated further. Further research is also needed to study the effect of bio-fertilization in response to drought stress under field conditions. It would also be interesting to compare the effects of inoculum containing different fungal species and spore concentrations.

Author Contributions: N.A. performed the experiments, data analysis and wrote the manuscript. A.v.B. assisted in the laboratory analysis. C.S. conceived and designed the study in greenhouse conditions. M.T.L. assisted with data analysis and revised the manuscript. All authors have read and agreed to the published version of the manuscript.

Funding: This work was financially supported by the National Research Foundation through the South African Research Chairs Initiative (UID 84647).

Institutional Review Board Statement: Not applicable.

Informed Consent Statement: Not applicable.

Data Availability Statement: Data of this study is available from the authors.

Conflicts of Interest: The authors declare no conflict of interest.

\section{References}

1. Mehraban, A.; Tobe, A.; Gholipouri, A.; Amiri, E.; Ghafari, A.; Rostaii, M. The effects of drought stress on yield, yield components, and yield stability at different growth stages in bread wheat cultivar (Triticum aestivum L.). Pol. J. Environ. Stud. 2019, $28,739-746$. [CrossRef]

2. The Food and Agriculture Organization (FAO). World Food and Agriculture Statistical Year Book 2013; FAO: Rome, Italy, 2013.

3. Lobell, D.B.; Burke, M.B.; Tebaldi, C.; Mastrandrea, M.D.; Falcon, W.P.; Naylor, R.L. Prioritizing climate change adaptation needs for food security in 2030. Science 2008, 319, 607-610. [CrossRef] [PubMed]

4. Daryanto, S.; Wang, L.; Jacinthe, P.A. Global synthesis of drought effects on maize and wheat production. PLoS ONE 2016, 11, e0156362. [CrossRef]

5. Emam, Y.; Shekoofa, A.; Salehi, F.; Jalali, A.H. Water stress effects on two common bean cultivars with contrasting growth habits. Arch. Agron. Soil Sci. 2010, 9, 495-499. 
6. Belay, J.A.; Zhang, Z.; Xu, P. Physio-morphological and biochemical trait-based evaluation of Ethiopian and Chinese wheat germplasm for drought tolerance at the seedling stage. Sustainablity 2021, 13, 4605. [CrossRef]

7. Jafari-Shabestari, J.; Corke, H.; Qualset, C.O. Field evaluation to salinity stress in Iranian hexaploid wheat landrace accessions. Genet. Resour. Crop. Evol. 1995, 42, 147-156. [CrossRef]

8. Quiroga, G.; Erice, G.; Aroca, R.; Chaumont, F.; Ruiz-Lozano, J.M. Enhanced drought stress tolerance by the arbuscular mycorrhizal symbiosis in a drought-sensitive maize cultivar is related to a broader and differential regulation of host plant aquaporins than in a drought-tolerance cultivar. Front. Plant. Sci. 2017, 8, 1056. [CrossRef]

9. Elliott, J.; Deryng, D.; Müller, C.; Frieler, K.; Konzmann, M.; Gerten, D. Constraints and potentials of future irrigation water availability on agricultural production under climate change. Proc. Nat. Acad. Sci. USA 2014, 111, 3239-3244. [CrossRef]

10. Rui-Lozano, J.M.; Porcel, R.; Azcón, R.; Aroca, R. Regulation by arbuscular mycorrhizae of the integrated physiological response to salinity in plants: New challenges in physiological and molecular studies. J. Exp. Bot. 2012, 63, 695-709.

11. Candar-Cakir, B.; Arican, E.; Zhang, B. Small RNA and degradome deep sequencing reveals drought -and tissue-specific microRNAs and their important roles in drought-sensitive and drought-tolerant tomato genotypes. J. Plant. Biotech. 2016, 14, 1727-1746. [CrossRef]

12. Min, H.; Chen, C.; Wei, S.; Shang, X.; Sun, M.; Xia, R. Identification of drought tolerant mechanisms in maize seedlings based on transcriptome analysis of recombination inbred lines. Front. Plant. Sci. 2016, 7, 1080. [CrossRef] [PubMed]

13. Anjum, S.A.; Tanveer, M.; Ashraf, U.; Hussain, S.; Shahzad, B.; Khan, I. Effect of progressive drought stress on growth, leaf gas exchange, and antioxidant production in two maize cultivars. Environ. Sci. Pollut. Res. Int. 2016, 23, 17132-17141. [CrossRef] [PubMed]

14. Marulanda, A.; Barea, J.M.; Azcon, R. Stimulation of plant growth and drought tolerance by native microorganisms (am fungi and bacteria) from dry environments: Mechanisms related to bacterial effectiveness. J. Plant. Grow. Regul. 2009, 28, 115-124. [CrossRef]

15. Gholamhoseini, M.; Ghalavand, A.; Dolatabadian, A.; Jamshidi, E.; Joghan, A.K. Effects of arbuscular mycorrhizal inoculation on growth, yield, nutrient uptake and irrigation water productivity of sunflowers grown under drought stress. Agri. Water Manag. 2013, 117, 106-114. [CrossRef]

16. Chitarra, W.; Pagliarani, C.; Maserti, B.; Lumini, E.; Siciliano, I.; Cascone, P. Insights on the impact of arbuscular mycorrhizal symbiosis on tomato tolerance to water stress. Plant. Physiol. 2016, 171, 1009-1023. [CrossRef] [PubMed]

17. Al-Karaki, G.N.; Al-Raddad, A. Effects of arbuscular mycorrhizal fungi and drought stress on growth and nutrient uptake of two wheat genotypes differing in drought resistance. Mycorrhiza 1997, 7, 83-88. [CrossRef]

18. Ruiz-Lozano, J.M.; Porcel, R.; Azcón, R.; Bárzana, G.; Aroca, R. Contribution of arbuscular mycorrhizal symbiosis to plant drought tolerance: State of the art. In Plant Responses to Drought Stress: From Morphological to Molecular Features; Aroca, R., Ed.; Springer: Heidelberg/Berlin, Germany, 2012; pp. 335-362.

19. Yooyongwech, S.; Samphumphuang, T.; Tisarum, R.; Theerawitaya, C.; Chaum, S. Arbuscular mycorrhizal fungi (AMF) improved water deficit tolerance in two different sweet potato genotypes involves osmotic adjustments via soluble sugar and free proline. Sci. Hort. 2016, 198, 107-117. [CrossRef]

20. Aroca, R.; Del Mar Alguacil, M.; Vernier, P.; Ruiz-Lozano, J.M. Plant responses to drought stress and exogenous ABA application are modulated differently by mycorrhization in tomato and an ABA-deficient mutant (Sitiens). Microb. Ecol. 2008, 56, 704-719. [CrossRef]

21. Dietz, K.J.; Foyer, C. The relationship between phosphate and photosynthesis in leaves, Reversibility of the effects of phosphate deficiency on photosynthesis. Planta 1986, 167, 376-381. [CrossRef]

22. Mercy, M.A.; Shivashankar, G.; Bagyaraj, D.J. Mycorrhizal colonization in cowpea is host dependent and heritable. Plant. Soil 1990, 121, 292-294. [CrossRef]

23. Moucheshi, A.; Heidari, B.; Assad, M.T. Alleviation of drought stress effects on wheat using arbuscular mycorrhizal symbiosis. Int. J. Agri. Sci. 2012, 2, 35-47.

24. Emmett, B.D.; Lévesque-Tremblay, V.; Harrison, M.J. Conserved and reproducible bacterial communities associate with extraradical hyphae of arbuscular mycorrhizal fungi. ISME J. 2021, 15, 2276-2288. [CrossRef]

25. Mohammad, M.J.; Pan, W.L.; Kennedy, A.C. Seasonal mycorrhizal colonization of winter wheat and its effect on wheat growth under dry land field conditions. Mycorrhiza 1998, 8, 139-144.

26. Abdul-Wasea, A.A.; Elhindi, K.M. Alleviation of drought stress of marigold (Tagetes erecta) plants by using arbuscular mycorrhizal fungi. Saudi J. Biol. Sci. 2011, 18, 93-98.

27. Augé, R.M. Water relations, drought and vesicular-arbuscular mycorrhizal symbiosis. Mycorrhiza 2001, 11, 3-42. [CrossRef]

28. Yang, X.; Chena, X.; Gea, Q.; Li, B.; Tongc, Y.; Li, Z.; Kuanga, T.; Lu, C. Characterization of photosynthesis of flag leaves in a wheat hybrid and its parents grown under field conditions. Plant. Physiol. 2007, 164, 318-326. [CrossRef]

29. Khan, A.; Pan, X.; Najeeb, U.; Tan, D.K.Y.; Faha, S.; Zahoor, R.; Luo, H. Coping with drought: Stress and adaptive mechanisms, and management through cultural and molecular alternatives in cotton as vital constituents for plant stress resilience and fitness. Biol. Res. 2018, 51, 1-17. [CrossRef] [PubMed]

30. Ortiz, N.; Armada, E.; Duque, E.; Roldán, A.; Azcón, R. Contribution of arbuscular mycorrhizal fungi and/or bacteria to enhancing plant drought tolerance under natural soil conditions: Effectiveness of autochthonous or allochthonous strains. Plant. Physiol. 2015, 174, 87-96. [CrossRef] 
31. Sánchez-Romera, B.; Ruiz-Lozano, J.M.; Zamarreño, Á.M.; García-Mina, J.M.; Aroca, R. Arbuscular mycorrhizal symbiosis and methyl jasmonate avoid the inhibition of rot hydraulic conductivity caused by drought. Mycorrhiza 2016, 26, 111-122. [CrossRef] [PubMed]

32. Manavalan, L.P.; Guttikonda, S.K.; Tran, L.S.P.; Nguyen, H.T. Physiological and molecular approaches to improve drought resistance in soybean. Plant. Cell Physiol. 2009, 50, 1260-1276. [CrossRef] [PubMed]

33. Tanveer, M.; Shahzad, B.; Sharma, A.; Khan, E.A. 24-Epibrassinolide application in plants: An implication for improving drought stress tolerance in plants. Plant. Physiol. Biochem. 2019, 135, 295-303. [CrossRef]

34. Sheng, M.; Tang, M.; Zhang, F.; Huang, Y. Influence of arbuscular mycorrhiza on organic solutes in maize leaves under salt stress. Mycorrhiza 2011, 21, 423-430. [CrossRef]

35. Ruiz-Lozano, J.M. Arbuscular mycorrhizal symbiosis and alleviation of osmotic stress. New perspectives for molecular studies. Mycorrhiza 2003, 13, 309-317. [CrossRef]

36. Wu, Q.S.; Xia, R.X.; Zou, Y.N.; Wang, G.Y. Osmotic solute responses of mycorrhizal citrus (Poncirus trifoliata) seedlings to drought stress. Acta Physiol. Plant. 2007, 2, 543-549. [CrossRef]

37. Zhang, Z.; Zhang, J.; Huang, Y. Effects of arbuscular mycorrhizal fungi on the drought tolerance of Cyclobalanopsis glauca seedlings under greenhouse conditions. New For. 2014, 45, 545-556. [CrossRef]

38. Abid, M.; Tian, Z.; Ata-Ul-Karim, S.T.; Liu, Y.; Cui, Y.; Zahoor, R. Improved tolerance to post-anthesis drought stress by predrought priming at vegetative stages in drought-tolerant and -sensitive wheat cultivars. Plant. Physiol. Bioch. 2016, 106, 218-227. [CrossRef] [PubMed]

39. Liu, T.; Li, Z.; Hui, C.; Tang, M.; Zhang, H. Effect of Rhizophagus irregularis on osmotic adjustment, anti-oxidation and aquaporin PIP genes expression of Populus $\times$ canadensis 'Neva' under drought stress. Acta Physiol. Plant. 2016, 38, 191. [CrossRef]

40. He, Z.; He, C.; Zhang, Z.; Zou, Z.; Wan, H. Changes of antioxidative enzymes and cell membrane osmosis in tomato colonized by arbuscular mycorrhizae under $\mathrm{NaCl}$ stress. Coll. Surf. B Biointer. 2007, 59, 128-133. [CrossRef]

41. Abdel Latef, A.A.H.; Chaoxing, H. Effect of arbuscular mycorrhizal fungi on growth, mineral nutrition, antioxidant enzymes activity and fruit yield of tomato grown under salinity stress. Sci. Hortic. 2011, 127, 228-233. [CrossRef]

42. Mehdy, M.C.; Sharma, Y.K.; Sathasivan, K.; Bays, N.W. The role of activated oxygen species in plant disease resistance. Plant. Physiol. 1996, 98, 365-374. [CrossRef]

43. Hajiboland, R.; Aliasgharzadeh, A.; Laiegh, S.F.; Poschenrieder, C. Colonization with arbuscular mycorrhizal fungi improve salinity tolerance of tomato (Solanum lycopersicum L.) plants. Plant. Soil 2010, 331, 313-327. [CrossRef]

44. Arnon, D.I. Copper enzymes in isolated chloroplasts. Polyphenol oxidase in Beta vulgaris. Plant. Physiol. 1949, 24, 1-15. [CrossRef]

45. Liang, Y.; Urano, D.; Kang-Ling, L.; Hedrick, T.L.; Gao, Y.; Jones, A.M. A nondestructive method to estimate the chlorophyll content of Arabidopsis seedlings. Plant. Meth. 2017, 13, 1-10. [CrossRef]

46. Bates, L.; Waldren, R.P.; Teare, J.D. Rapid determination of free proline for water stress studies. Plant. Soil 1973, 39, 205-207. [CrossRef]

47. Farissi, M.; Ghoulam, C.; Bouizgaren, A. Changes in water deficit saturation and photosynthetic pigments of Alfafa populations under salinity and assessment of proline role in salt tolerance. J. Agri. Sci. 2013, 3, 29-35.

48. Irigoyen, J.J.; Einerich, D.W.; Sanchez-Diaz, M. Water stress induced changes in concentrations of proline and total soluble sugars in nodulated alfalfa (Medicago sativa) plants. Plant. Physiol. 1992, 84, 55-60. [CrossRef]

49. Chow, P.S.; Landhäusser, S.M. A method for routine measurements of total sugar and starch content in woody plant tissues. Tree Physiol. 2004, 24, 1129-1136. [CrossRef]

50. Halliwell, B.; Gutteridge, J.M.C. The importance of free radicals and catalytic metal ions in human diseases. Mol. Asp. Med. 1985, 8, 89-193. [CrossRef]

51. Zeb, A.; Ullah, F. A Simple spectrophotometric method for the determination of thiobarbituric acid reactive substances in fried fast foods. J. Anal. Methods Chem. 2016, 2016, 9412767. [CrossRef]

52. Ghoulam, C.; Foursy, A.; Fares, K. Effects of salt stress on growth, inorganic ions and proline accumulation in relation to osmotic adjustment in five sugar beet cultivars. Environ. Exp. Bot. 2002, 47, 39-50. [CrossRef]

53. Velikova, V.; Yordanov, I.; Adreva, A. Some antioxidant systems in acid rain treated bean plants; protective role of exogenous polyamines. Plant. Sci. 2000, 151, 59-66. [CrossRef]

54. Abdi, N.; Ltaief, B.; Hemissi, I.; Bouraoui, M.; Sifi, B. Oxidative stress in pea (Pisum sativum L.)-rhizobia symbiosis induced under conditions of salt stress. J. Agr. Sci. Tech. 2019, 21, 957-968.

55. Dicko, M.H.; Hilhorst, R.; Gruppen, H.; Traore, A.S.; Laane, C. Comparison of content in phenolic compounds, polyphenol oxides and peroxidase in grains of fifty sorghum varieties from Burkina Faso. J. Agric. Food Chem. 2002, 50, 3780-3788. [CrossRef]

56. Bargaz, A.; Faghire, M.; Farissi, M.; Drevon, J.J.; Ghoulam, C. Oxidative stress in the root nodules of Phaseolus vulgaris is induced under conditions of phosphorus deficiency. Acta Physiol. Plant. 2013, 35, 1633-1644. [CrossRef]

57. Hori, K.; Wada, A.; Shibuta, T. Changes in phenoloxidase activities of the galls on leaves of Ulmusvidana formed by Tetraneura fuciformis. Appl. Entom. Zool. 1997, 32, 365-371. [CrossRef] 